\title{
Correction: Quality assessment of the enhanced gonococcal antimicrobial surveillance program in Thailand, 2015-2016
}

Weston E, Lertpruek S, Tongtoyai J. Quality assessment of the enhanced gonococcal antimicrobial surveillance program in Thailand, 2015-2016. Sex Transm Infect 2017;93:A28-9. doi: 10.1136/ sextrans-2017-053264.71. The authors have requested a correction to the author list and affiliations for their abstract. While E Weston did indeed present this at ISSTDR in Rio last year, she did so in place of her Thai colleagues who were unable to be there. They noticed an error in the published book of the author list and the correct author list should be as follows: Siritrapanan $\mathrm{M}^{1,2}$, Lertpruek $\mathrm{S}^{3}$, Tongtoyai $\mathrm{J}^{3}$, Cherdtrakulkiat $\mathrm{T}^{3}$, Buasakul $\mathrm{P}^{1,2}$, Sukwicha $\mathrm{W}^{3}$, Chonwattana $\mathrm{W}^{3}$, Weston $\mathrm{E}^{4}$, Dunne $\mathrm{EF}^{3,5}$, Sirivongrangsan $\mathrm{P}^{2}$

The correct author affiliations should be:

${ }^{1}$ Bangrak STIs Center, Bureau of AIDS, TB, and STIs Bangkok, Thailand

${ }^{2}$ Department of Disease Control and Prevention, Thailand Ministry of Public Health, Nonthaburi, Thailand

${ }^{3}$ HIV/STD Research Program, Thailand Ministry of Public Health - U.S. Centers for Disease Control and Prevention Collaboration, Nonthaburi, Thailand Division of HIV/AIDS Prevention, U.S. Centers for Disease Control and Prevention, Georgia, USA

${ }^{4}$ Division of STD Prevention, U.S. Centers for Disease Control and Prevention, Georgia, USA

${ }^{5}$ Division of HIV/AIDS Prevention, U.S. Centers for Disease Control and Prevention, Georgia, USA

(c) Author(s) (or their employer(s)) 2018. No commercial re-use. See rights and permissions. Published by BMJ.

Sex Transm Infect 2018;94:442. doi:10.1136/sextrans-2017-053264.71corr1

Check for updates 